\title{
Why It Took so Long to Complete Undergraduate Thesis at English Department: Students' and Lecturers' Voices
}

\author{
Yulhenli Thabran, Nunung Fajaryani \\ English Department of FKIP Univ. Jambi (UNJA), Jambi, Indonesia \\ English Department of FKIP Univ. Jambi (UNJA), Jambi, Indonesia \\ yulhenli@unja.ac.id; nfajaryani81@gmail.com
}

\begin{abstract}
In this study, we seek to explore issues surrounding thesis writing process and completion among English department students. It has been years that students in our department spend relatively longer in completing bachelor thesis. It takes them minimum two semesters or even more to complete their thesis. On average, most students spend four and half years to five years to finish their study. One of the biggest hurdles is the difficulty to complete thesis within short time. Writing thesis within short period of time is very demanding for students and not many of them can do that. With a case study approach, we interviewed eleven lecturers and eight students to get true account on both sides on what make thesis writing is so difficult and time-consuming project. The results of semistructured interview reveal very diverse perspective on that issue. However, the recurring themes that unite both parties among others are: insufficient planning, bad time management, low proficiency of English, low motivation and self-discipline, involved in other activity besides thesis writing, insufficient knowledge for doing research, and student-supervisor relationship.
\end{abstract}

Keywords: thesis writing process, a case study, semi-structured interview, thesis completion

\section{INTRODUCTION}

One of the hardest parts in students' career including undergraduate students or S1 is to fulfill the requirement for writing up their 'skripsi' (or thesis). For consistency of terminology used, we will use thesis instead of skripsi as referent when we talk about students' academic writing submitted for bachelor degree (Jubhari, 2003). Each undergraduate student or S1 must submit a piece research as a partial requirement to obtain their bachelor degree, though there is a plan from the new Minister of Research and Technology Directorate Higher Education, Prof. Muhammad Nasir in 2015 to make thesis as an optional course in undergraduate study (Wicaksono \& Halim, 2015). However, as far as we are concerned there is no regulation that has been passed by the government yet, stating that thesis writing is an optional for undergraduate students when this paper was drafted. Automatically, many students in Indonesian still regard thesis as "specter" in achieving their ambition to finish their study (Bahri, 2013). The apparent reason for this is that they have to wrestle with the complexity of thesis format and time they should spend with both of their supervisors. Some of them managed to finish on time, but many of them spent longer to write their thesis. In some extraordinary cases, a few students spend fourteen semesters or seven years to finish their study. All of this is caused by very slow process of thesis writing completion. The tragic scenario is they have to leave without gaining their degree or drop out from university.

There are many studies that have been conducted throughout the globe devoting on the issue of thesis writing processes and challenges faced by non-native speakers especially in master and doctoral levels. To mention a few of them here as follows: Cadman, 2000; Grant, 2003; Ho, Wong \& Wong, 2010; Lessing \& Lessing, 2004; Sadeghi \& Khajepha , 2015; Strauss, 2012; Wang \& Li, 2008, 2011. Since these studies are intended for master and PhD students' thesis writing problems, in some contexts they are different from what we have done in terms of their purposes and problems being highlighted.

Though the study of thesis writing experience in Indonesia is under study, there is a handful of study related to undergraduate thesis writing experience (e.g.: 'Aini, 2014; Dwihandani, Marhaeni \& Suarnajaya, 2013). However, both studies only give partial sketch to nuance of complexity and daunting journey how to become a 'sarjana'. They only looked at the issue from students' perspective quantitatively. The analysis stopped with figures and percentages. Their findings did not answer thoroughly why some problems happened that way. Viewing the drawbacks of their studies, we would like to cover the issue from both sides, that is, supervisors and students' voice who interacted in the process of thesis production. In this study, we will examine some potential factors which hamper students to complete their thesis on time. We will contrast the opinions of supervisors and students in identifying the causes of slow progress of thesis writing project.

\section{METHODS}

The primary method in investigating students and supervisors' opinion is a case study approach under the framework of qualitative design. In the opinion of Creswell (2007, p. 73), "case study research involves the study of an issue explored through one or more cases within a bounded system (i.e., a setting, a context)". With regard to his statement, the case in our project is why English department students tend to spend long time to complete their thesis. 
To collect audio data, a purposeful sampling technique by means of a convenience case strategy was used. Creswell (2007, p. 126) stated that convenience case is used because the sites or individuals are easy for researchers to access and collect data from. The participants in our research project are some English lecturers and English Department students. The total number of participants is 11 lecturers and 8 students. The majority of lecturers in this study hold master degrees either from local university or overseas university. Four of them have doctoral degree from overseas. And 6 of the lecturers are senior lecturers while the rest of them are still junior. While for student participants, 4 of them still work on their thesis when this study was conducted and the other 4 had graduated or completed their thesis.

For eliciting data, we used semi-structured interview technique which was done after the participants agreed to give their consent by signing an informed consent form. The interviews were conducted in English. The interviews lasted between 20 minutes to 48 minutes, or, 07 hours: 41 minutes: 47 seconds in total. The raw data from interviews were later transcribed verbatim as said by the participants spontaneously during the interviews. As the result, there are some grammatical mistakes in their speech found. For analyzing the data, we did data coding and grouped the similarities and differences of opinions based on emerging themes. To achieve trustworthiness and credibility of qualitative study, according to Yin (2011, p.19), the research procedures should be 'transparent'. He further explained that data must be possible to be inspected by other researchers and checked by participants. In the context of our study, the audio data and transcribed interviews can be accessed by participants and others especially who have interest to this study.

\section{RESULTS AND DISCUSSION}

Having read and done critical examination to the opinions given by lecturers and students in the interviews, our data can be broken down in the emerging themes below. The discussion will be done with contrasting the findings with what other studies had found earlier.

\subsection{Insufficient Thesis Planning}

Good planning is very important for students in doing a project such as writing thesis. Based on lecturers' perspective, there are some issues that will hamper students from completing their thesis right on time in relation with their planning. For instance, lecturer 07 mentioned that "mostly students having problem with finding titles". He explained further that this was caused by they just copied someone's work. This lecturer said that he had to turn down a title because it was merely a copycat from what other had done, or the proposed title was too close with his previous student's thesis. Similar problem was also identified by Dwihandani, Marhandani and Suarnajaya (2013) and also 'Aini (2014). In their study, the students voted finding titles were among the highest percentage as thesis prevalent problems.
Other issue which also plays apart in hindering students to complete their thesis on time is the plan thesis design. This issue raised by lecturer 01 , in which he said: "the most stressful part is chapter 2". He said that when students wanted to write something scientifically such as a thesis, they had to read and review many scientific sources. However, according to him, many of the students had low ability to comprehend academic texts such as scholarly research articles. That's why according to him this section is one of the hardest parts to write for his students. He further explained that when the students chose a qualitative design, the students were more likely to find it hard to analyze the data. He argued that it happened because "they didn't know how to interpret the pile of data".

In contrast with lecturers' views, some students in this study did not seem to pay careful attention to thesis planning. They might not consider careful thesis planning would help them to finish their thesis much faster. An evidence for not caring thesis planning is "I live far way from campus, that's why I rarely met my supervisors" (Student 6). According to this student, she felt embarrassed to go campus because most of her friends had finished their thesis some years ago. She managed to complete her thesis in her seventh year eventually. Other thing that had hindered her from completing her thesis earlier was she worked in an English course and gave private lessons to some secondary school students at their home. She said: "I was tired when I arrived home and I could not work on my thesis". She said that she quit her job when she wanted to work on her thesis more seriously.

Another student confessed that she tried to escape from thesis planning by ignoring it for a while. She said that: "I spent some times watching movies in cinema with friends and I turned to social media when I got frustrated or I got stuck in my writing" (Student 2). She confessed that she did these kinds of activities to get some inspirations and ideas. In fact, according to her, she felt regret because she just wasted her precious time. This student finally finished her thesis and sit in final exam after more than one year.

\subsection{Bad Time Management}

One of the biggest enemies for students who write their thesis is to organize their time wisely. When the participated lecturers were asked about their time policy in supervising students, many of them acknowledged that they did care about it. This was described in the following response: "It is a must I think. I always ask my students and they need to write by themselves. That they should finish within you know my time frame. That's about six months" (Lecturer 1). Another lecturer in this study also raised the same thing: "... you can finish your proposal within three months... and in one and half month you must present your proposal. I always told my student" (Lecturer 2). These two examples are good example how the lecturers gave encouragement to work hard and be wise with time.

However, the situation was not always true for some students. One student who was not too strict with time explained why she acted that way: "I cannot guarantee 
whether this [thesis] will finish within six months or a year. It actually depends on the lecturers or it depends on me" (Student 3). This student believes that she didn't need to be too strict with time because she cannot predict the progress of her work. She finally finished her thesis within two semesters or within a year last year. She would have completed her thesis faster if she had pushed herself a bit harder. The act likes she has done can be classified as procrastination in which she wasted her time without unclear reasons. A study by Ho, Wong and Wong (2010) in a graduate school in an American university also found similar problem in which the graduate students made many excuses for not completing their dissertations until the deadline was over. They got called ABD (All But Dissertation) students. They never finished their dissertations even though they had fulfilled all requirements including completing their course works.

\subsection{Low Proficiency of English}

Writing thesis in English for students whose mother tongue is not English is difficult job to do. Both lecturers and students acknowledge that English proficiency is one of the biggest problems for writing up their ideas in English. For example, a lecturer pointed out: "That's the biggest problem that I found. Most of them even don't know which one is subject which one is the verb and grammatical errors and mistakes. I don't know how they differentiate [subject and predicate] because they already [have] got structure, grammar 1, 2 and 3" (Lecturer 1).

Similar concern is also put forward by a student as follows: "I don't know how to write it in good grammar. It also used many technical vocabularies and long narration" (Student 7). Some lecturers suggested weak students to consult with smart students in reducing the issue of sentence structure and grammar problems. However, writing thesis in English is not only how to have correct grammar but also how to work with existing literature, integrating and synthesizing what have been done by others. This skill needs long time to acquire and practice in order to use that in scientific writing like thesis.

It is a pity that in our department we do not have a study skill center for helping students who are writing their thesis. In advanced country such as in Australia, students get many advantages of study skill center where they could consult with teaching staffs there for language problems and thesis writing issues (Wong \& Li, 2008). Supervisors or lecturers in our study refused to act as a proofreader and editor because the jobs were too much for them. They said they did not have time for checking all grammatical mistakes and dictions. They just leave it to students to do the job. They only suggested the smart students help weaker students in terms of grammar.

\subsection{Low Motivation and Self-Discipline}

The lecturers in this study argued that many students have low motivation and self-discipline in doing their thesis project. A lecturer or lecturer 8 once had to dismiss his supervisee when this student urged him to give feedback immediately after disappeared for one semester. To quote this lecturer: "You never met me for six months and now you asked me to correct you thesis within one week. I want to check it for one semester too". He had to talk to the head of department to inform he did not want to supervise that student anymore. He got his wish. He was replaced by someone else in the department not long after that.

One student or student 8 had a unique experience. He said he could not focus on his thesis when he opened his laptop. In his words: "I was easily carried away by the habit of opening other files in my computer when I wanted to work on my thesis". He remarked that he was distracted with that habit and hardly wrote anything for his thesis. This prolonged his time to complete his thesis on time, and plus with his low academic skill in writing up his thesis.

Another student or student 4 also had bad selfdiscipline, that is, she confessed that she preferred to sleep for long hours if she got annoyed by her mother's question: "When would you finish your study". She had a hard time to finish her thesis: "I know I have to finish this thesis even though I do not like it". She finished her thesis after more than one year. Dwihandani, Marhandani and Suarnajaya (2013) also found the same trend in their study. They claimed motivation and discipline were two things that often slowed down the progress of thesis writing process to great extent.

\subsection{Involved in other Activity besides Thesis Writing}

Two activities that students in our department claimed responsible for slow process of thesis completion is working and compulsory activities from campus, that is, kukerta (field trip training) and PPL (teacher training session in school). However, there is good news for student from 2013 generation about the status of kukerta. With the revision of curriculum, kukerta is no longer obligatory subject for them. This may save them from losing much time in the process of writing up their thesis. However, PPL is still a compulsory for them. The best strategy to deal with this is to set up clear time frame to meet with supervisor when they want to consult their thesis. One lecturer or lecturer 7 argued that PPL activity or students' teaching activity must be allocated before student entering the phase of writing thesis. He believed the students would find it difficult to divide time for teaching at practice school with working on their thesis.

For many students, kukerta is a time-consuming activity which often made them late in completing their thesis. One of the students in this study or student 1 remarked his disapproval as follows: "I practically did not do anything when I went to village for kukerta for three months. There was no progress in my thesis during that time. I backed to work and meet my supervisors after I finished kukerta." He finally managed to complete his thesis and sit in final exam after more than one year. We believe that our students will complete their thesis much faster when kukerta is really removed from curriculum. It only PPL that still left to hinder many students in their thesis writing process. However, this subject can be arranged when students are not in time of thesis writing session. 
3.6. Insufficient Knowledge for Doing Research

Something that always raised by lecturers is the lack of students' knowledge in conducting research properly. Even though there are some subjects that prepare students for thesis writing process, there are still many problems faced by both supervisors and students in the actual writing process. However, our department has introduced a new subject specially intended for thesis writing, namely, "Thesis Writing" in 2016. This may not solve every problem faced by students, but at least it will reduce their problems to certain extent.

Regarding the insufficient knowledge, lecturer 1 believed that this was partly caused by their bad communication skill in terms of "communicating face-toface" with their supervisors and "their inability to communicate in written form". He further explained that most students did not know where to find their sources and comprehend the literature. He argued this made many students afraid to meet their supervisors to discuss their thesis progress.

From students' side, we found that they tend to come to their friends for advice when they faced problems. For example, student 7 remarked: "I preferred to go to my friend when I did not know what to do or I did not understand the comments given by my supervisors". He further commented that writing thesis was really hard for him since he had no previous experience and his ability too was not really good. In his words: "How can I write such long text and use technical vocabularies". He believed it took him some time to finish his thesis because of these problems.

One of lecturers in our study that is lecturer 10 has suggested a way to help students find potential topic for research. According him, "The complexity of thesis and its components hampered students to present their reports well and on time. As the results, there are many bad theses in our department. In my opinion, instead of requiring students to write complicated thesis, they could write their teaching practice (PPL) at schools as a major report." He believed this could shorten time for thesis writing.

\subsection{Student-Supervisor Relationship}

One of lecturers in this study commented that thesis writing is collaboration with three people in developing an idea into a thesis. In the course of its journey, there is up and down the relationship between supervisees and supervisors. To work effectively in accomplishing the mission, the three of them should support each other and communicate regularly in solving academic and non-academic problems caused by thesis writing process.

Some studies found that the slowness of thesis completion is due to strained relation between supervisee and supervisors (Ho, Wong \& Wong, 2010; Wang \& Li, 2008, 2011). Some supervisors may not read the students' draft critically or may not help wholeheartedly because of personal or academic problems. One of the lecturers in our study or lecturer 8 told his bad experience as follows: "One of my supervisees used soft power to hasten his turn for sitting in final exam. The student made his parents meet me in office and at home several times. It was really annoyed me. I also learned later that he used this kind of strategy to board of examiners. His parents met each of examiners to plead to help their son in thesis exam". According to lecturer 8, finally the student passed in the exam though he only received bare pass or $\mathrm{C}+$. He said that "we found out that he was underperformed in the thesis exam and he did not know how to conduct the research properly".

Another lecturer or lecturer 2 experienced unpleasant things with one of his supervisees. According to this lecturer, many of his supervisees did not seem to respect him in terms of communication. He complained his supervisees tend to force him to sing the approval when they wish to enroll in seminar and thesis exam. He also disliked the way the students texted him: "The messages sound as if a command to me". He explained he had talked to the students to change their behaviors. Similar comments also put forward by lecturer 1 in which he said "The students lacked of politeness". He did not explain in detail what he meant by politeness in his words, but we assume that this relates to the ways of his students interacted in the process of consultation and communicating.

From student sides, we found interesting evidence in which the situation potentially jeopardize good relation between student and supervisor. This student or student 3 in our study claimed that her supervisor was rude to her both in the consultations and in thesis exam. She said: "He shouted to me in thesis exam-'I told you hundred times' when I could not defend my argument to examiner". Her supervisor is a senior lecturer in our department and he has high temperament. He is often being rude to other students and also to his colleagues. The ways he talked to supervisee (student 3) might have offended her in some way.

\section{CONCLUSION}

Thesis writing is difficult to do and it needs a lot of effort to accomplish it. Drawing from data in our findings, we can conclude that this process needs solid team work between two supervisors and supervisees. Students must work hard to draft their thesis and for supervisors, they must actively help and guide students to go through difficult time in thesis writing process. Some problems may be relatively easy to be solved, but others may be difficult to solve without giving much thoughts and energy. We believe one of the difficult problems that is hard to get rid is being procrastinated. In our data, both lecturers and students believe that "laziness" or "procrastination" is something that hard to deal with. Other people may suggest him or her to be more active and diligent, but it is he or she that must change him or herself.

Thing that may not very hard to improve may be the required knowledge to conduct research. Students have been prepared to write a thesis at the end of their study through studying related subjects. However, many students may not get to the level that is required to conduct research and write thesis report. One of lecturers or lecturer 3 in our study has 
made a critical comment about this: "The undergraduate students did not know anything about thesis writing. They did not have any experience to write thesis. It is our job to guide and to teach them. Don't stress them out". Similar comment also put forward by lecturer 1 in which he said: "thesis is only partial requirement to obtain their degree". Therefore, according to him there is no reason for us to prevent them from getting their degree.

\section{REFERENCES}

'Aini, W. (2014). Kesulitan-kesulitan mahasiswa PLS FIP UNP dalam menyusun skripsi. Pedagogi, 14(2), 13-21.

Bahri, S. (2013). Skripsi 'hantu' bagi mahasiswa. Serambi Indonesia. Retrieved from http://aceh.tribunnews.com/2013/12/14/skripsi-hantubagi-mahasiswa?page $=3$

Cadman, K. (2000). 'Voices in the air': Evaluations of the learning experiences of international postgraduates and their supervisors. Teaching in Highger Education, 5(4), 475-491. DOI: 10.1080/713699170

Creswell, J. W. (2007). Qualitative inquiry and research design: Choosing among five approaches ( $2^{\text {nd }}$ ed.). Thousand Oaks, CA: Sage.

Dwihandani, L.A., Marhaeni, A.A.I.N., \& Suarnajaya, I.W. (2013). The analysis of the factors affecting students' difficulties in writing thesis in the English department of Mahasaraswati University. E-journal Program Pascasarjana Universitas Pendidikan Ganesha Program Studi Pendidikan Bahasa, 2, 1-12. Retrieved from http://pasca.undiksha.ac.id/ejournal/index.php/jurnal_bahasa/article/view/903

Emilia, E. (2008). Menulis tesis dan disertasi. Bandung: Kerjasama Sekolah Pascasarjana Universitas Pendidikan Indonesia dengan C.V. Alfabeta.

Grant, B. (2003). Mapping the pleasures and risks of supervision. Discourse: Studies in the Cultural Politics of Education, 24(2), 175-190. DOI: $10.1080 / 01596300303042$

Herdian. (2012, September 2012). Kesulitan menulis skripsi. [blog post]. $\quad$ Retrieved from https://herdy07.wordpress.com/2012/09/13/galau-dalammunyusun-skripsi/

Ho, J.W., Wong, L.C.J., \& Wong, P.T. (2010). What helps and what hinders thesis completion: A critical incident study. International Journal of Existential Psychology \& Psychotherapy, 3(2), 117-131.

Jubhari, R.S. (2003). Cultural influences on the rhetorical structure of undergraduate thesis introductions in bahasa Indonesia and English. (Unpublished doctoral dissertation). Monash University, Melbourne, Australia.

Lessing, N., \& Lessing, A. C. (2004). The supervision of research for dissertations and theses. Acta Commercii, 4(1), 73-87.

Sadeghi, K., \& Khajepha, A.S. (2015). Thesis writing challenges for non-native MA students. Research in
Post-Compulsory Education, 20(3), 357-373. DOI: 10.1080/13596748.2015.1063808

Strauss, P. (2012). 'The English is not the same': Challenges in thesis writing for second language speakers of English. Teaching in Higher Education, 17(3), 283-293.

Wang, T., \& Li, L.Y. (2008). Understanding international postgraduate research students' challenges and pedagogical needs in thesis writing. International Journal of Pedagogies and Learning, 4(3), 88-96. DOI: 10.5172/ijpl.4.3.88

Wang, T., \& Li, L.Y. (2011). 'Tell me what to do' vs. 'guide me through it': Feedback experiences of international doctoral students. Active Learning in Higher Education, 12(2), 101-112. DOI: 10.1177/1469787411402438

Wicaksono, K., \& Halim, F. (2015). Menristek: Mahasiswa S1 nanti tidak wajib buat skripsi. Viva.co.id. Retrieved from http://nasional.news.viva.co.id/news/read/629264menristek--mahasiswa-s1-nanti-tidak-wajib-buat-skripsi

Yin, R.K. (2011). Qualitative research from start to finish. New York and London: The Guilford Press. 